\title{
Imagem, Sujeito, Poder
}

Entrevista com Marie-José Mondzain Tradução: Vinícius Nicastro Honesko (UFPR)

Nos últimos anos, a imagem se tornou um dos temas teóricos em voga: dela não se fala apenas em termos de história da arte, mas também em termos sociológicos, de teoria das mídias e de filosofia política. Em uma de suas entrevistas precedentes, a senhora menciona que na época em que o tema da imagem não estava tão na moda era preferível falar de semiologia, do "campo de especialidade que se desenvolve entre a filosofia e a gestão dos signos sociais", e que, durante o reinado da semiologia, a imagem era abordada em termos de leitura: "lia-se" as imagens. A senhora poderia indicar por que a semiologia da imagem finalmente perdeu seu crédito? $O$ que supostamente a substitui no nível do pensamento contemporâneo da imagem?

Marie-José Mondzain: $O$ controle industrial e comercial das imagens está inteiramente centrado na ideia de que é preciso que elas sejam de todo co-extensíveis ao discurso que as habita - é assim que se vendem ideias, pessoas, coisas. A quantidade de produções visíveis não tem nada a ver com o excesso de imagem que designei como seu próprio, como sua propriedade. Minha relação com a semiologia e a linguística é de curiosidade, de interesse. Mas, ao mesmo tempo, sempre vejo que esses textos são - com frequência virtuosos do ponto de vista conceitual e que desenvolvem os instrumentos de uma microcirurgia dos objetos -, na maior parte dos casos, redigidos com um espírito de inteligibilidade ou controle que não necessariamente revelam uma vontade de poder, mas que são, para mim, saberes acadêmicos. A imagem é tratada como um objeto, um objeto do saber que tem seus experts e é suscetível de especialidade.

Até um período relativamente recente - dado que a questão da imagem se tornou cada vez mais preponderante desde o início do século XX -, aqueles que escreviam sobre as imagens eram tanto os historiadores da arte quanto os produtores 
da imagem. Mas percebíamos que a filosofia aí não encontrava seu regime: deixamos a imagem se desenvolver sem nos colocar questões. Também estou muito interessada pelas leituras das imagens feitas por historiadores como Daniel Arasse ou Georges Didi-Huberman que, de fato, integraram a seus modos de análise a dimensão propriamente filosófica. A leitura renovada de Aby Warburg permitiu uma espécie de oxigenação em relação ao exército bem armado dos semiólogos, dos estruturalistas, dos linguistas, que acabaram asfixiando totalmente seu objeto, reduzindo-o ao estado de coisa. Eu diria que, para certos analistas da imagem e de sua história, a redescoberta de Aby Warburg ou o retorno a Walter Benjamin são as aberturas libertadoras em relação à polissemia da imagem. Por polissemia quero dizer que a imagem é indecidível, jamais unívoca. Sua equivocidade, sua liberdade, seu excesso, aí retomam fôlego. Saímos do laboratório instrumentalizado e da maestria.

Mas por que também não estou na mesma posição que esses pensadores? De início, porque não sou historiadora da arte e não realizei o mesmo trajeto a partir da filosofia. Considerando que a imagem havia sido causa de guerras, de destruições e de crimes, que pessoas são mortas por sua causa e que outras tomaram o poder com ela, optei por olhar para onde estavam aqueles que as faziam, aqueles que as queriam, aqueles que as destruíam, aqueles que as defendiam, e àqueles para quem elas eram verdadeiramente uma aposta de vida e morte. Cheguei a um terreno onde estava verdadeiramente sozinha. Iniciei a partir do que se passa com a imagem nos monoteísmos. Era preciso, então, traduzir os textos; passei muito tempo na leitura e tradução desse primeiro material.

É por isso que, para responder sua pergunta - é preciso uma nova leitura da imagem pois a semiologia não vale mais nada? -, não estou nesse regime da questão. Coloquei a questão em sua genealogia: como a questão da imagem foi posta? Em que momento a imagem se tornou uma questão que provoca, de um e de outro lado, a repulsão, a delação, a idolatria, a glorificação política, a perversão? Em que momento essa questão foi amarrada? Passei tempos em lugares um pouco solitários, uma vez que se tratava do mundo proto-cristão, bizantino, iconoclasta, e me encontrei em uma comunidade científica, a dos filósofos da antiguidade, para a qual a imagem não era um bom objeto, e entre os historiadores da Idade Média oriental, para quem a imagem era apenas um problema teológico. Construir um objeto filosófico nessas condições não era simples. Mas penso ter em parte atingido meu objetivo, isto é, ter convencido de que havia uma construção filosófica do objeto chamado imagem em tal momento histórico. E é desse momento que é preciso partir. Eis aí a gênese. 
Passemos às questões de conceitos para mencionar seu percurso teórico e especificar o vocabulário "imagem, ícone, ídolo", constitutivo de sua obra. Nos seus livros Image, icône, économie ${ }^{1}$ e Le commerce des regards, a senhora emprega os conceitos "ícone" e "ídolo" para falar da imagem e de suas raízes religiosas. Ainda que esses dois termos sejam muito próximos, eles têm significações opostas: a senhora indica que ícone, imagem da paz, dá sua legitimidade ao ídolo, o qual funciona como um funil do olhar. Ao mesmo tempo, a senhora afirma que " $A$ imagem é independente do regime da verdade". A senhora poderia especificar a distinção que a partir disso faz entre o ícone, o ídolo e a imagem em geral?

Em vez de dizer a imagem em geral, diria que "imagem" é um termo genérico que designa o gênero cujas espécies seriam o ícone e o ídolo. Mas isso também não é de todo verdade.

Voltemos, assim, às palavras. Uma vez que estamos conversando em língua francesa, somos obrigados a passar por tal língua para falar de coisas que foram pensadas primeiramente em hebraico, em grego e, então, em latim. Esses termos não se recobrem totalmente: a palavra "imagem" não é a tradução do latim “imago", esta que não é a tradução do grego "eikon”. Então vamos, aqui também, tomar as coisas de modo histórico, ir ao terreno histórico onde as coisas se colocaram e aconteceram, em situação de crise, e onde a imagem se constituiu como questão ao mesmo tempo filosófica e política. É importante saber que as coisas primeiramente foram ditas em grego. Mesmo que nas igrejas ortodoxas chamamos de eikon os objetos que nelas vemos - denominados "ícones" -, é preciso lembrar que a palavra eikon, em grego, não é um substantivo. Quando Platão ou, mais tarde, os padres da Igreja falam de eikon, eles não designam uma coisa. Eles designaram um modo de aparição no campo do visível, pois eikon, em grego, é análogo a uma forma verbal no particípio presente. Quando um grego quer dizer a coisa, a coisa icônica, ele toma a raiz dessa palavra, eikon, e a coloca no neutro, pois eikon é uma ramificação verbal no particípio presente ativo e no feminino. Quando ele a coloca no neutro - para as coisas, em grego, o neutro termina normalmente com " $m a$ " ela se torna "eikonisma", como "apeikasma", "fantasma". Tomemos o exemplo do verbo "fazer" (pratto, prattein): se você utiliza a palavra "práxis", é a ação, é uma palavra no feminino, como "eikon"; mas a coisa é "pragma”, que deu pragmático, e práxis deu "prático". O grego distingue o estatuto da coisa da ação que a traz à existência: "poiésis" é o gesto de criar, "poiéma" é o poema. Ao contrário, as palavras no neutro também terminam com "on" - como "eidolon", que dá "ídolo" - e designam, no visível,
1. Há uma recente tradução para o português: MONDZAIN, Marie-José. Imagem, Ícone, Economia. As fontes bizantinas do imaginário contemporâneo. Rio de Janeiro: Contraponto; Museu de Arte do Rio, 2013. Trad.: Vera Ribeiro. 
2. N.T.: A filósofa utiliza o termo "semblant", que diz respeito ao que se dá a ver, à aparência, ao aspecto exterior de algo. Assim, a depender do uso feito pela autora, traduzimos ora por "semblante" ora por "aparência".

\section{N.T.: "Ressemblant", que diz} respeito ao que se "assemelha", que se "parece".

4. N.T.: "Semblance", por sua vez, também diz respeito à noção de aspecto, mas também indica algo que evoca alguma outra coisa, próximo, nesse sentido, ao termo ressemblant. as operações das coisas, dos objetos, em sua consistência opaca e presente, em seu efeito de real. Ergon não é poièsis, nem todo fabricante é poeta.

Voltemos agora ao eikon, que foi traduzido por "ícone". Eu prefiro traduzi-lo por "semblante", pois a tradução literal de $e i$ kon é "semblante", no particípio presente, é a "coisa aparente". O segundo sentido da palavra eikon é "semelhante" "s: "semblante", "aparência do outro", portanto, "semelhante", "quanto ao retorno da aparência"4. É muito importante compreender que o grego diferencia as operações do visível das operações do sensível e que, se o platonismo rejeitou as imagens, em grande parte - salvo em alguns casos, como no Timeu, em que a imagem serve à visão cosmológica do mundo - é porque a aparência coloca um problema ontológico à filosofia. Pois se uma coisa que parece não é, ela não tem um estatuto ontológico de verdade. Ela é inapreensível. Platão não confunde eikon e eidolon, e coloca o eikon ao lado daquilo que parece. E, de fato, para ele é ainda ontologicamente insuficiente. É insuficiente porque sobre aquilo que parece não se pode construir um saber. O que Platão vê aí é absolutamente justo e eu o defendo: não há saber sobre a imagem. Para Platão essa é sua fraqueza, para mim é sua força e seu destino político. Como analisei em meu livro Le commerce des regards, a filosofia platônica só reconhece dignidade ao que permite construir um saber e uma verdade, associando o ser das coisas à verdade do discurso sobre tal ser das coisas, o que faz com que, ontologicamente, a imagem não possa ter seu lugar na dignidade metafísica de uma verdade sobre o ser. Mas Platão diz, apesar de tudo, que essa aparência não é não-ser: é uma insuficiência. O fato de que a aparência não seja nem ser nem não-ser coloca o próprio Platão em dificuldade: ele diz que, verdadeiramente, a imagem não é - Ontos mè onta. É ontologicamente que ela não tem ser. Assim, ela participa, ela é ao mesmo tempo on e mè onta, ela está entre o ser e o não-ser. O fato de ser "entre" é o modo do eikon: é ser "entre", entre o ser e o nada, o modo de aparição do mundo que coloca o olhar em crise, que faz com que nós vejamos, duvidemos, suspeitemos e nos inquietemos. Ao mesmo tempo, talvez isso tenha a ver - pensa Aristóteles, mais do que Platão - com os regimes daquilo que os homens partilham na cidade, coisas pouco certas, verossimilhanças, regimes opinativos da palavra, ignorâncias sobre o amanhã, contingências, fragilidades: partilhamos muito mais fragilidades e dúvidas do que certezas em uma cidade. Platão gostaria que o rei fosse filósofo e que o matemático fosse filósofo e, portanto, que o matemático fosse o rei e o filósofo, ou seja, ele gostaria que tudo isso fabricasse um poder um pouco sólido; enquanto o interesse do pensamento aristotélico buscava compreender a política como um regime de fragilidade e de dúvida, de 
inconstância, de ignorância, pois a vida política é temporal e, portanto, ligada à morte do passado e à ignorância do futuro, e o presente era feito, trabalhado, por essa desaparição das coisas e por essa ignorância do que vem. E a imagem esta aí, entre todas essas coisas que são partilhadas pelos cidadãos. Desse modo, o eikon, esse regime de aparência, antes de ter sido um objeto, foi designado pela língua grega, com desconfiança ou esperança, como um regime singular da aparência e da verossimilhança, da doxa e do endoxon.

Quanto aos ídolos, sem dúvidas é preciso esperar uma reflexão mais aprofundada dos Padres da Igreja para lhes dar um estatuto no coração do pensamento da imagem. De início, o ídolo é um objeto que mediatiza as relações entre os viventes e os mortos, entre os poderes ocultos e as impotências reais. Ele não é o antônimo do ícone antes do debate doutrinal sobre a imagem. Por razões que enunciei em minhas obras - a saber, que há uma crise do olhar na produção das imagens entre instâncias do poder -, sou tocada pelo fato de que a imagem, nesse debate, é denunciada, criticada ou defendida de acordo com a questão: "o eikon e o eidolon são a mesma coisa ou são coisas diferentes?" Os iconoclastas dizem que todo eikon só se deixa conhecer como eidolon, portanto, há idolatria. A resposta dos iconófilos, triunfante - e que penso ser extremamente interessante -, é que o único meio de salvar o regime da imagem é dizer que entre eikon e eidolon há incompatibilidade, uma distinção definitiva; há até mesmo uma contradição. Eikon designa uma relação, eidolon designa um objeto. E, portanto, os iconófilos puderam dizer aos iconoclastas: vocês é que, ao destruírem os ícones, são idólatras, uma vez que diante da fragilidade e aparência do ícone vocês veem apenas o objeto. Assim, vocês têm um olhar idólatra para aquilo que não deveria ser um objeto. É seu olhar que reifica o objeto da fragilidade, da aparência. Fazemos referência aos dois lados da questão sobre o ídolo. Mas se quisermos verdadeiramente responder a tais questões - "o que é um olhar que reifica?” e "o que é um olhar que respeita a fragilidade do ícone?" -, a cada vez, só vamos nos deparar com a palavra "imagem" que surge como problema. Daí a reflexão sobre a "imagem".

Ora, quando em francês dizemos "imagem", há um desconforto - que encontramos também nas línguas anglo-saxônicas, as quais não nos auxiliam muito -, pois a grande reflexão de fundação é feita em grego e encontrou a sutileza de um desdobramento plural das palavras em latim. $O$ francês exige muita explicação aí onde o grego, que a respeito disso também se explicou, encontra palavras para especificar os regimes: tanto articulados quando incompatíveis uns com os outros. Se pesquisarmos sobre o latim "imago" teremos mais nuances, sabendo que o interessante do latim imago é que é muito ligado às 
práticas funerárias e, portanto, sem dúvida ligado à experiência da morte, do desaparecimento e do que é retido daqueles que não estão mais aqui. Mas percebemos que a imago flutuou entre os latinos, tanto que, no latim medieval, palavras diferentes circularam e se esforçaram para dar conta da dimensão espiritual da imago. Santo Agostinho e os padres latinos necessariamente precisam se ocupar da imagem por razões teológicas evidentes, uma vez que a encarnação é uma estrita questão de visibilidade da imagem. Encontraremos reflexões muito sutis e apaixonantes a respeito de "signum", de "species", "figura", "fictio", "respicta", a coisa pintada, "res ficta", a coisa imaginada. Entre "imago" e "imagines" acontecerão também idas e vindas.

Assim, como dar conta dessas vibrações lexicais quando escrevemos em francês? E quem escreve em francês? Todo esse tempo que passei trabalhando entre noções gregas que faziam distinções de extrema sutileza, para, em seguida, falar de imagem a meus contemporâneos, era preciso retrabalhar os efeitos do próprio vocabulário. A maior parte do tempo fui obrigada a dizer: chamo "visibilidades" o modo no qual aparecem no campo do visível objetos que ainda esperam sua qualificação por um olhar. Irei chamar "imagem” o modo de aparição frágil de uma aparência constituinte para olhares subjetivos, em uma subjetivação do olhar. A “imagem” é efetivamente, no meu léxico, o que constitui o sujeito. O eikon é o modo de aparição dos signos que permite a estes se constituir para permitir a partilha do simbólico. O "ídolo" é o modo no qual a questão do desejo pode se afundar e se aniquilar totalmente, quando o desejo de ver dá a si mesmo o objeto de sua completa satisfação, digamos, de seu gozo. E, assim, quando os antigos criticam o ídolo, é preciso não se esquecer jamais de que há essa suspeita, legítima, em relação a objetos que se consomem e que consomem o sujeito. O ídolo é então aquilo que ameaça a subjetividade, uma vez que essa relação é de consumo passional, fusional e fantasmática. Nesse sentido, o desejo de destruição é inseparável do destino dos ídolos. Finalmente, quando coloco "imagens" no plural, designo o conjunto de produções do visível às quais ainda não dei qualificação, ainda não sabendo a que operações do olhar elas vão dar lugar.

Várias vezes a senhora colocou em evidência o fato de que a imagem encontra seu lugar entre a visão e a representação, que ela necessita de uma construção, uma formação prévia do olhar de um sujeito falante (e que ela é, nesse sentido, inacessível aos olhares dos outros mamíferos, por exemplo). Trata-se, assim, no caso do olhar humano, de uma competência cultural. A senhora poderia especificar qual é a natureza da relação entre o sujeito e a imagem? 
Em nossas sociedades de hoje, encontramo-nos diante da designação massiva da palavra "imagem" a tudo o que é produzido no visível: fotos, obras de arte, publicidades, televisão, cinema, documentos. Todas são “imagens”. Sim, mas em que são imagens? Sob qual título? Por meio de meu trabalho, gostaria de dar conta dos regimes de pensamento que foram fundadores em relação à definição da imagem: fundadores não quanto a seu estatuto de objeto, mas quanto àquilo a que ela remete nas operações do olhar que lhe dirige um sujeito. As coisas se esclarecem a partir do momento que classificamos a imagem na relação que ela tem com o olhar do sujeito, com o cruzamento de olhares e com a troca, com a circulação de signos, distinta do comércio das coisas, daquilo que chamo o comércio de olhares. É o olhar do sujeito que dá à imagem seu estatuto de "eikon", de "eidolon", de "fantasmata", de "fantasma"; é a maneira de construir o olhar que reifica ou não seu objeto. Posso tomar os maiores lugares do olhar e da aparição frágil da história da arte e fazer deles objetos idolátricos. E é por isso que os artistas surrealistas e, em particular, os dadaístas, lutaram contra a arte burguesa, necessariamente idólatra e que reifica a arte como mercadoria. Por meio dos objetos de arte, eles jogaram e atacaram os ídolos da cultura burguesa para mostrar que foram as operações do olhar que foram lentamente desqualificadas pelo comércio dos objetos. Eis as coisas que hoje nos concernem de modo vital.

Minha abordagem convida cada um de nós, enquanto sujeitos, a nossa potência subjetiva de qualificação do visível; convida a reconhecer no visível signos em um campo de signos que circulam; convida a dizer que o que chamamos de imagem pode ser, ou não, constituinte ou destituinte dos sujeitos que as olham.

É aí que as coisas se complicam na definição, pois é preciso explicar em que, antropologicamente, a imagem é constituinte da relação entre os sujeitos, e do próprio sujeito. Para dar conta da abordagem patrística e dos efeitos bastante modernos que ela poderia ter para nós, e do interesse que por ela poderíamos ter para nutrir nosso pensamento da imagem, o problema mencionado me obrigou a ir à antropologia e à psicanálise. Ambas me fizeram ver como, genealogicamente - do ponto de vista filogenético (a constituição da humanidade) de um lado, ou ontogenético (a constituição do sujeito humano em sua individualidade e singularidade) do outro -, a questão da imagem era parte envolvida na gênese do sujeito. E dessa maneira eu compreendia que um sujeito que era privado de imagens, que não podia construir uma imagem de si, havia produzido em nossa sociedade, tão plena de imagens, uma verdadeira patologia da imagem. Isto é, que havia um sofrimento, uma patologia, um abuso do olhar, que fazia com que houvesse uma 
destituição da imagem, um abuso do narcisismo primário: como nos constituímos na imagem que temos de nós mesmos em relação a um outro sujeito, em relação ao olhar de um outro sujeito? A psicanálise, a psicopatologia, os textos sobre a psicose, muito me esclareceram sobre o fato de que a imagem era uma aposta constituinte para os sujeitos em sua relação matricial, em sua origem. E, igualmente, do ponto de vista filogenético, eu percebia que, no fundo, a própria humanidade assinalava-se como humanidade pela inscrição dos signos que, antes de dar testemunho de uma linguagem ou mesmo de uma escritura, designavam o modus imaginis, o modo da imagem, como primeiro gesto de separação. Tornando-se a condição necessária ao acesso de cada um de nós às operações simbólicas da palavra, a imagem pode ser um separador, um operador de separação. Um bebê, por exemplo, que não tem nenhum meio de construir e apreender sua própria imagem - sinestésica e visual ao mesmo tempo - é uma criança que jamais terá acesso à palavra. E, assim, nos autismos, nas afasias, nas psicoses infantis, tratamos e retomamos as coisas pela questão da imagem: fazemos desenhar. Recomeçamos pela construção da imagem.

Se o sujeito se constrói, então compreendemos que o que os Padres designavam pela palavra eikon era algo constituinte das relações entre os sujeitos. Desse modo, o que é constituinte do político, isto é, do viver juntos no sentido grego, assim o é porque é constituinte dos procedimentos, dos protocolos de subjetivação. Não há sujeito sem imagem. É muito importante. O ídolo torna-se, em seu processo de reificação, muito mais o modo pelo qual o visível não produz o sujeito, mas o reduz ao estado de objeto: o ídolo é o que reifica o sujeito, ao ser uma reificação da imagem.

É nesse sentido que digo que há uma verdadeira patologia da imagem, a qual faz com que aqueles que não têm imagem de si mesmos, senão através de objetos, sejam reduzidos ao estado de objeto e persuadidos de que é a apropriação e o consumo dos objetos que vão lhes permitir construir uma imagem de si mesmos. Do ponto de vista inicial do sofrimento social de hoje, pedir o reconhecimento de identidade por meio do consumo dos objetos produz violências. Isto é, alguém que não tem nenhuma maneira de se fazer reconhecer em um campo social por um outro olhar, procura chamar a atenção desse olhar pelo consumo de objetos que lhe dão uma identidade em relação ao olhar do outro. Para ele serão necessárias Nike, Lacoste, etc. O consumo das marcas torna-se um marcador identitário. De uma só vez vamos nos tornar qualificados, identificados, através dos objetos que estamos à altura de consumir. Fazemos de nós mesmos objetos - e pensamos ser esse tornar-se objeto o único meio de obter o olhar do outro e um processo de 
reconhecimento, portanto, de dignidade. Estamos em uma história de loucos: as pessoas tornam-se criminosas porque não têm nenhuma imagem de si mesmas. Elas são de tal forma desqualificadas internamente que têm uma dor absoluta, que engendra uma violência absoluta, que dá vontade de matar, de morrer.

Com o objetivo de especificar o papel cultural do "eikon", voltemos mais uma vez à terminologia. Em seu livro Image, icône, économie, a senhora dirige sua atenção para o fato de que, nos contextos não cristãos (clássicos e pagãos), a palavra “oikonomia" designava tudo o que era gestão e administração, ao mesmo tempo, dos bens (economia) e das visibilidades (ikonomia). A senhora assinala igualmente que o termo "economia" tornou-se, no momento da crise iconoclasta bizantina, o leitmotiv da defesa icônica. A senhora poderia elucidar as razões dessa retomada do termo "economia" no contexto cristão?

Para mim, foi uma descoberta saber que os Padres da Igreja tinham, seguindo São Paulo, construído toda a doutrina do "eikon" sobre algo que eles opunham à "teologia". A imagem é uma relação econômica, isto é, anti-teológica. A economia é a dimensão real, histórica, é a dimensão temporal do olhar. Ela designa essa negociação ininterrupta dos olhares entre o que está presente e o que está ausente. É dizer que só há vida dos signos em uma relação com a ausência e em uma separação da presença. É magnífico que "a economia" tenha se tornado o conceito operatório dessa construção, pois isso toca a totalidade das trocas humanas e vai, efetivamente, do comércio e circulação de signos até o comércio das coisas e a circulação das mercadorias. A mesma palavra! A que isso se refere? À nossa responsabilidade ética e política no campo do visível. Cabe a nós escolher. Os objetos, face a isso, não podem nada. Eles não fazem nada, eles não matam, eles esperam.

Ora, a palavra "economia" não é uma invenção dos cristãos, mas é retomada do grego clássico: foi muito utilizada por Xenofonte e por Aristóteles. Ela designa toda a gestão e administração doméstica e, em Aristóteles, é tomada em suas relações com a administração da cidade. Como, para Aristóteles, o modelo familial permanece o modelo da economia política, passamos da gestão e administração do patrimônio pelo pai à gestão e administração dos bens e serviços no campo social. E mesmo o "oikonomos" era já um intendente. É ele o encarregado de gerir, administrar, regular, compatibilizar, zelar, pelo equilíbrio na produção, na difusão, no gasto.

A palavra "economia" foi traduzida ao latim essencialmente por duas palavras: "dispositio" e "dispensatio". "Dispositio" é como o grego "systema”; é o conceito de organização que está 
por trás e a partir do qual encontramos o sentido na "oikonomia": a organização. O grande "oikonomos" na teologia é Deus, o grande organizador, o ordenador do mundo, o arquiteto cosmológico. É também por que a economia foi identificada de modo tão rápido com a providência, com o "cosmos", em grego, querendo dizer ao mesmo tempo a ordem, a beleza e o mundo. Estamos em um mundo onde só podemos admirar e anotar a inteligibilidade, a regularidade, a ordem e a beleza - "cosmos". A origem desse "cosmos" é um "oikonomos": uma entidade, um princípio de organização racional e estético sem falha. É por isso que "oikonomid" se tornou "pronoid", providência.

Mas, a partir do momento que essa providência, no mundo cristão, entregou-se ao exercício histórico admirável da economia, produzido pela imaginação cristã da encarnação, a providência e a ordem do mundo foram mudadas. Em todos os casos, elas se implementam em um regime diferente daquele que conhecemos como teologia cosmológica: trata-se do regime da história dos homens como gasto de Deus (Dispensatio). Essa mudança se deve à encarnação que consiste em duas coisas fundamentais. Primeira, a temporalização da divindade que nasce, vive e morre: a divindade se torna temporal e histórica; segunda, a divindade, que não é visível, torna-se visível. Temporalização e visibilidade são as duas características da encarnação. A partir do momento que Deus a quis, que a providência organiza isso, será preciso integrar essa história, essa narração, com a "oikonomia" e dizer que o fenômeno da encarnação faz parte do plano geral da divindade, tornado um plano não simplesmente invisível, inteligível e cósmico, mas histórico e visível.

Assim, "eikonomia" - cuja homofonia, em grego, com "oikonomia" assinalei, pois, para o grego, "ol" e "el" são ambos pronunciados “i”-, o direito do ícone, a lei do ícone, é também a lei da casa, a nova habitação. Ele se fez Verbo, Ele se fez Pai e Ele veio habitar entre nós. Desse modo, essa lei da habitação, do "oikos", e do ícone, são completamente homofônicas; e, penso, não apenas homofônicas: elas são sinônimas. Não podemos separar o registro icônico do registro histórico e do registro providencial, de gestão e de administração do mundo. Apenas - como compreenderam muito bem os latinos ao dizer que há não apenas "dispositio", reorganização, mas também "dispensatio", gasto essa economia é, ao mesmo tempo, em um regime computável, um investimento, com tudo o que isso representa de perdas e benefícios. E, em uma boa economia, é preciso que o gasto seja um investimento que traga benefícios. Por consequência, a ressurreição é o modo pelo qual a perda será superada por um benefício incalculável, incomensurável: a Redenção. Há aí uma economia, um investimento e um gasto - pois não é pouca coisa enviar um filho, uma imagem, e entregá-lo à paixão e à morte: 
é um grande risco econômico assumido pela própria divindade. Mas tal risco é bem gerido, uma vez que isso dura até agora e que é uma empresa que não conheceu a bancarrota.

A aposta de seu livro Image, icône, économie era a de desvelar as fontes do imaginário contemporâneo na querela iconoclasta na época bizantina (725-843). Ainda que com frequência falemos sobre as "guerras das imagens" do ataque terrorista de 11 de setembro de 2001, em Nova York, poderíamos mencionar também a recente lide seguida à publicação das caricaturas de Maomé em um jornal dinamarquês. Para a senhora, podemos identificar a censura contemporânea à iconoclastia bizantina? Há diferenças entre essas duas estratégias de eliminação das imagens?

Todo poder tem suas imagens e recusa ao contra-poder ter sua visibilidade. Nisso estamos perto da problemática iconoclasta: quem toma o poder tem o monopólio da imagem e de sua significação. E, portanto, interrompe a busca icônica do outro, ou o censura.

Entretanto, a iconoclastia bizantina não era uma censura: era uma maneira de destruir uma instância de poder ao recusar as imagens àqueles que delas se serviam para tomar o poder, justamente por reconhecer que tal era o poder das imagens. Essa prática consistiu em suprimir imagens relevantes de uma categoria do poder que se queria eliminar para substituí-las por imagens do poder que se queria constituir. E aquele que as destruiu, ao mesmo tempo, compreendeu bem que as imagens tinham um poder, uma vez que atribuiu a si mesmo o poder de fazer suas próprias imagens. Os iconoclastas não são an-icônicos: eles são contra as imagens religiosas, as imagens no campo da Igreja, para desenvolver um imaginário profano, um imaginário do poder; há até mesmo uma arte iconoclasta. Assim, não se trata de uma eliminação das imagens, mas de uma eliminação do outro enquanto utiliza suas imagens para tomar o poder.

Ademais, em Bizâncio, a imagem não é um pretexto. Ao contrário, ela é a aposta do poder e a própria razão da crise: todos queriam tomar o poder com suas próprias imagens e suprimir as imagens do outro para tomar-lhe o poder. Isso quer dizer que a imagem é, nesse momento, reconhecida como portadora de um poder de convicção, de submissão e de representação do poder do qual se quer privar seu adversário.

Quando as caricaturas de Maomé são proibidas, isso não é feito porque se quer tomar o poder, suprimir um poder às imagens. É em um contexto de todo diverso, em uma outra 
paisagem política, que é a do terror ideológico. Muitos não foram enganados por essa história de censura das caricaturas de Maomé, dizendo que a produção e a denúncia das caricaturas eram uma operação de propaganda nos dois sentidos. Aí, a questão da imagem era extremamente secundária: nem mesmo eram caricaturas que faziam rir, com algum tipo de interesse gráfico. Apenas se aproveitou da caricatura como uma propaganda para inflamar um conflito ideológico que é somente a máscara de um conflito de tipo econômico. O Islã e as convicções religiosas são hoje a aposta na qual se opõem potências econômicas no mercado do ópio, do petróleo, das armas. Ora, em vez de dizer que, neste momento, as pessoas morrem por causa do ópio, do petróleo e do mercado das armas, criou-se uma martiriologia terrificante que diz que as pessoas se matam porque há um choque de culturas, uma incompatibilidade de culturas. Mesmo no momento das caricaturas de Maomé, dizia-se que o conflito advinha da fratura cultural entre os regimes de religiões. Ora, para mim, tudo isso era apenas simulacro, uma montagem teatral para esconder as apostas políticas do conflito.

Tomemos um outro exemplo, aquele dos Budas de Bamiyan: eles estavam ali há muitos séculos, em um país islâmico que, até então, neles não via inconvenientes. Para eles eram ídolos, o Deus dos outros, e isso não lhes concernia uma vez que não ameaçava sua própria divindade. Somente a partir do momento em que o outro se tornou inimigo, eles perceberam que os Budas de Bamiyan faziam parte do patrimônio mundial da cultura defendido pela Unesco, a representante da cultura ocidental com a qual eles estão em guerra. Decidiram atacar o Ocidente, tocá-lo onde declara seus mais altos valores. A saber, não quiseram matar o budismo, mas atacar a ideia que o Ocidente faz da obra de arte e do patrimônio cultural. É também por isso que filmaram a cena da destruição. Eu mesma recebi uma imagem em que o filme da destruição se torna um auto-de-fé: filma-se o auto-de-fé do filme para fazer um filme de auto-de-fé das imagens.

Estamos aí em uma espécie de circularidade das visibilidades - e o 11 de setembro de 2001 foi a fórmula exemplar do mesmo princípio - que assim funciona: uma vez que vocês são uma sociedade espetacular, nós também iremos fazer espetáculo e fazer de vocês os espectadores privilegiados de sua destruição... Eles sabem que Hollywood é inseparável dos modos narrativos escolhidos pelo Pentágono para construir suas narrações guerreiras e sua legitimidade. São os cenaristas de Hollywood que fornecem ao Pentágono os cenários para falar aos jovens soldados e convencê-los da grandeza heroica e legítima de seu sacrifício no Iraque. As pessoas adoram que lhes contemos histórias. George Bush disse em um discurso: "People like stories". 
Então lhes contamos histórias. E como os militares não sabem contar histórias, pedimos para que Hollywood escreva histórias que iremos contar aos militares. No mundo islâmico, em guerra econômica e financeira com os Estados Unidos, é parecido. Estamos em uma gestão espetacular: a organização econômica e industrial do espetáculo torna-se o objeto de narrações lendárias - no sentido em que fazemos lendas em torno de imagens, para torná-las compreensíveis - que precisam ser contadas para legitimar operações estritamente imperialistas, de um lado e do outro. O ícone de Bin Laden é inesgotável dos dois lados.

Assim como a imagem foi verdadeiramente uma grande aposta no momento da guerra iconoclasta, também a gestão industrial do espetáculo coloca-se como pano de fundo aos verdadeiros contextos do conflito. Mas também não é o contrário da iconoclastia, porque, na questão da iconoclastia, a denúncia dos ídolos faz parte da problemática escondida do poder. Hoje assistimos a uma gestão industrial dos ídolos. Cada um quebra os ídolos do outro pois o próprio dos ídolos, de modo contrário às imagens, é que podemos quebrá-los. Os Padres já haviam compreendido muito bem que não podemos quebrar a imagem, pois a imagem não é um objeto. Quando vocês destroem um ícone, vocês não destroem a imagem. Vocês atacam a sacralidade, mas isso não pode atacar a imagem: vocês destroem o objeto. A imagem é indestrutível.

Em 2002 a senhora participou de um projeto de exposição Iconoclash, concebido e realizado pelo filósofo Bruno Latour e pelo artista Peter Weibel. A aposta teórica da exposição era chamar a atenção para a problemática da produção e destruição das imagens existentes nos três domínios culturais diferentes: a ciência, a arte e a religião. A senhora era membra do comitê científico desse projeto; como a senhora o julgaria em face do pensamento teórico da imagem em nossos dias?

Essa exposição, para mim, foi um pouco um problema, pois a problemática que Bruno Latour queria apresentar provinha diretamente de meu trabalho sobre a economia icônica e a iconoclastia. Sem dúvidas foi por isso que ele me associou ao projeto: porque a maneira com a qual abordei a questão da iconoclastia havia sugerido que ele poderia abordar o conjunto da problemática da imagem em campos diferentes sob o signo da positividade da própria destruição e da reversibilidade das interpretações da violência no campo da criação. Isso lhe permitiu - com a cumplicidade amigável de muitos teóricos e artistas - fazer uma exposição de fato atual, isto é, na qual era possível ver formas críticas, formas de ironia, formas de destruição, no 
sentido crítico e sarcástico, dadaísta, surrealista ou científico. Mas, por fim, em vez de ser um espaço onde colocar em crise a crença em todos os níveis, isso produziu uma exposição de arte contemporânea: a enésima exposição de arte contemporânea na qual expertos em arte contemporânea arranjaram-se, bem ou mal, para impor certo número de artistas como emblemáticos dessa positividade da destruição e dessa turbulência. Penso que, apesar da abundância das obras e dos textos, isso dissimulou mal uma fraqueza teórica e uma organização consensual sobre a questão da destruição: a exposição Iconoclash atraiu o mundo, queria fazer sorrir e ser ao mesmo tempo muito epicurista e agradável, pois o projeto dizia respeito a um grupo de pessoas talentosas e cúmplices que tinham estabelecida uma colaboração de longa data. Nada de conflituoso, não podendo dar à manifestação sua dimensão verdadeiramente política. Por certo é muito excitante para Bruno Latour, que é de uma grande inteligência filosófico-especulativa, dizer que se tornou o curador que preside eventos de cultura e de arte que cobrem, cada vez mais, todos os campos: a religião, a ciência, a arte. É um poder. Mas era proibido de falar do Islam em Iconoclash. O assunto é demasiado delicado! Enquanto poderíamos, ao contrário, ter feito uma seção extremamente interessante - sem indignidade, pelo contrário - para dizer que era agora ou nunca o momento de produzir um espaço de reflexão positiva sobre a interdição e a destruição. Mas os responsáveis tinham medo de que os terroristas chegassem a Karlsruhe! Isso não desqualifica o que foi mostrado, mas devo dizer que a ambição da empreitada assumiu um desejo de cobrir uma totalidade. Hoje as exposições são eventos no mercado da comunicação cultural. As ideias circulam, os objetos deixam-se reconhecer, mas não é certo que o pensamento tenha tido tempo de verdadeiramente se renovar. Em muitos casos, a publicação programática de um conceito não contribui para o avanço do pensamento. Entretanto, estamos contentes por ter visto objetos admiráveis que, de outro modo, jamais teríamos podido ver, pois se encontram do outro lado do mundo ou são desconhecidos da maior parte das pessoas... E mesmo se o objeto parece incongruente nesse lugar, e se o curador da exposição decidiu fazer dela algo completamente diferente, podemos nos contentar por tê-la visto.

O historiador pode fazer várias ligações, pode se tornar experto das articulações entre as imagens: por exemplo, entre os magníficos quadros do século XV que estavam em Iconoclash. Não tenho nada contra, mas, torná-las solidárias a um sistema é esquecer que elas excedem tal sistema. E quando elas são co-extensivas ao sistema, elas não são mais operantes. É por isso que as exposições temáticas são tomadas por um paradoxo interno: serem obrigadas a justificar a co-extensividade do conceito aos 
objetos que são apresentados e, se os objetos forem muito bem escolhidos, eles excedem em muito o projeto. Assim, eles fazem aparecer o caráter inoperante.

O que acho mais interessante, como modo de reunião dos objetos, é a exposição das coleções de alto nível. Somos convidados a seguir um olhar colecionador que pôde, durante uma vida, comprar coisas: tentamos entrar na história de um olhar, apreender o fio de uma sensibilidade com suas aberturas, seus riscos, seus transbordamentos. Vi a exposição da doação Daniel Cordier, em Toulouse, onde está tudo o que ele acumulou durante sua vida: lá pode ter um tronco de árvore, um objeto das Novas Hébridas, um talismã, um objeto da vida quotidiana, um quadro de Matta, desenhos de Henri Michaux. História de um olhar que se exerce por toda uma vida. Há obras de arte no meio de tudo aquilo que uma vida pôde recolher de bonito, de surpreendente, de improvável ou de inquietante.

Finalmente, eu me permitiria colocar-lhe uma última questão concernente à fotografia. No seu livro Image, icône, économie a senhora fala da fotografia com o intuito de colocá-la em paralelo com a imagem aquiropita (a imagem que não é feita pela mão do homem). A senhora assinala que, uma vez que todo gesto fotográfico coloca a questão da impressão, a invenção da fotografia foi acolhida como confirmação da possibilidade de produzir a imagem aquiropita pelo artefato e de fabricar as impressões fetiches, tais como o Santo Sudário e o Véu de Verônica. A senhora poderia indicar qual a natureza da relação entre essas imagens supostamente "verdadeiras" e a demanda de veracidade da fotografia documental?

A questão da impressão é muito ligada ao fato de que o texto ao qual você faz alusão é consagrado à construção do Santo Sudário de Turim. Portanto, a uma fotografia de tipo impressa e na qual se joga com a impressão fotográfica e a impressão de um corpo real. Dizendo que a fotografia, que já é uma impressão, era a fotografia de uma impressão que, ela mesma, era o negativo de uma fotografia. É certamente a fotografia sobreposta, em uma perspectiva indicial da fotografia. Hoje, a maior parte da produção fotográfica é digital, portanto, não mais indicial. Ela é por pixels, segundo um sistema binário, e permite todas as manipulações.

No que diz respeito à veracidade da fotografia, ainda na época em que era indicial, era já uma arte do falso, no sentido do simulacro habitado pela crença do espectador. As imagens não têm realidade ontológica. Eu disse há pouco, mesmo antes 
de falarmos sobre fotografia: o estatuto do eikon é uma aparência. Assim, o fato de que a fotografia possa ser uma punção em um estado do mundo não dá a prova desse estado do mundo por causa da fotografia.

Para compreender melhor, remeto a um filme de Jean Eustache que se chama Les photos d'Alix. Esse filme, absolutamente genial, consiste em mostrar uma jovem fotógrafa que mostra a um jovem, filho de Jean Eustache, fotos que ela tirou. Ela diz o que há, a data, a hora, o lugar, a estação do ano, os nomes, quem são as pessoas que vemos na foto. Há, portanto, uma relação com o real: compreendemos que ela tirou essas fotografias em Londres, há três meses, de noite, etc. Mas quando vemos a foto não vemos nada correspondente àquilo que ela diz. De início, há uma correspondência um pouco vaga com uma credibilidade que cresce. Em seguida, progressivamente, no correr dos $18 \mathrm{mi}-$ nutos e 18 fotos, estamos no fim do filme e vemos um quarto, uma escrivaninha diante de uma janela, o que há sobre a escrivaninha, uma lâmpada, um espelho. Ela diz: "ah, esta foto eu tirei há três meses em Fez, é um pôr-do-sol em Fez". "Podemos reconhecer Fez", dirá ela, e vemos a escrivaninha e a janela, etc.

Esse filme mostra bem que a foto remete a estados do mundo. Em determinado momento, ela diz "eis uma foto": vemos que tal foto é tirada dentro de um carro, o condutor é então tomado pelas costas, há o retrovisor e, no retrovisor, vemos longe ao fundo. "Esta é uma lembrança da infância, é a foto de meu pai, enfim, de meu padrasto, tal como eu sempre o vi; viajávamos juntos, era nos Estados Unidos, entre São Francisco e não sei mais onde, enfim, era nos Estados Unidos; eu estava atrás, via suas duas grandes mãos no volante e só via, de seu rosto, aquilo que se mostrava no retrovisor. É uma lembrança da infância". E ela diz: "É uma lembrança da infância, mas não como as crianças delas se lembram, e é por isso que esta foto é uma lembrança. Enfim, é a foto que fiz recentemente, de uma lembrança que tive". Pouco a pouco percebemos que estamos vendo uma foto de infância, mas não como são as fotos de infância: ela fotografou há um mês uma lembrança da infância. Não vemos nem seu pai nem os Estados Unidos: a foto está na provocação da palavra à cegueira que exige a composição do olhar. O objeto que vemos flutua entre elas como um espectro de um mundo que não existe mais, de sua infância, de um pai que não está mais aí, de um país: não vemos o porquê de, sobre essa foto, ela ter necessidade de dizer que foi há anos, nos Estados Unidos, uma vez que fora há um mês, na memória dessa viagem que fez com seu pai. Esse filme é uma obra-prima sobre a desrealização do olhar em face da imagem.

Aliás, o que ela diz, tecnicamente, sobre os objetos é verdade. Por exemplo, em certo momento, vemos uma foto como 
duas botas, como as de Van Gogh. Antes que as vejamos, vemos a fotógrafa dizer "bem, é uma foto que tirei em Londres, em um pub, gosto muito dos pubs", e, de pronto, vemos que a foto mostra, ao lado das botas, um vazio. Ela diz: "eu estava em pé, com esses dois homens; com este - ela mostra um sapato -, com este eu perdi contato, o outro é ainda um amigo, gosto muito da atmosfera dos pubs". Ela conta uma história. E então, de modo repentino, diz: "o que me importava nesta foto era, efetivamente, trabalhar com a falta de foco na parte de baixo - que está desfocada - e com essa luz branca - de fato, tudo está branco - que descia desde o canto - e também aí, realmente, há uma luz branca -, é uma lembrança da Inglaterra”. Sem parar, estamos entre o que vemos e o que ela diz mas não vemos: a referência ao quadro de Van Gogh e o que ela mostra ao jovem, o que ela faz entender ao mostrar-lhe. Essa mudança do que damos a ver, do que damos a entender, do que fazemos crer, é o regime da fotografia, compreendido neste o da fotografia documental.

O que dizemos, o que escrevemos, o que contamos, intrinsecamente faz parte daquilo que fazemos ver. Se mostramos a foto sem dizer nada, sem palavra, como um material bruto, nós a damos à visão de um outro sem construir uma relação entre o ver e o fazer ver por meio da palavra e da partilha da crença. A foto não é uma prova do real, mas ela sempre coloca em jogo, como toda imagem, a relação de confiança e de crença que um olhar tem em relação a um outro olhar.

Em meu trabalho sobre o fotojornalismo dou grande importância ao que é dito do país e do momento em que uma foto foi tirada, àquilo que me dão a ver, à razão pela qual tal foto fora tirada, e ao que ela pode significar para quem a tirou. Em muitos casos, penso ser a foto inútil, desinteressante ou excessiva, pois não se dirige mais a mim como alguém que partilharia a possibilidade de construir, de minha parte, o que ela quer dizer. Ainda que eu tenha necessidade de um efeito de real, a imagem o excede, e é sobre tal excesso que se constrói a liberdade do outro, a quem nos endereçamos. Mas se essa liberdade é abandonada, é preciso ver sobre qual base de partilha: há aí um caminho dos regimes de crença diferentes que podem ir da credulidade à confiança, e da confiança a uma necessidade de liberdade.

Acabo de escrever um texto em que homenageio Sophie Ristelhueber, pois penso que em seu trabalho sobre o Iraque e a Palestina - no qual não vemos nem a guerra, nem o guerreiros, nem as vítimas - ela não mostra cenas, nem teatraliza o conflito. Pelo contrário, é o que ela não mostra que faz ver e, portanto, compreender. Ela se considera totalmente oposta às fotos do fotojornalismo: não é uma reportagem, é um objeto político e, ao mesmo tempo, suficientemente artístico, pois ela compõe, trabalha, ela faz as coisas não importa como. 
Acho que isso nos esclarece também sobre o que temos direito de exigir dos fotojornalistas que trabalham em demasia, como na revista Choc, por exemplo, em que vemos até onde pode ir a obscenidade na apreensão do real. A obscenidade do real pode ser algo lamentavelmente trivial: é a pretensão de tudo mostrar, em vez de retirar. Assim, como diz Comolli para o cinema documentário: "quando vou fazer um documentário, começo por me perguntar sobre o que não vou mostrar. Começo decidindo o que não mostrarei”. Começamos pela retirada, depois vemos o que deixamos para ser visto: construímos o fora de campo. E para a fotografia é o mesmo: é preciso sempre construir seu fora de campo.

Entrevista publicada originalmente em: http://sens-public.org/ spip.php?article 500\&lang $=\mathrm{fr}$ 